\title{
International Students' Coping Strategies and Psychological Adaption during Early the COVID-19 Outbreak Period in China
}

\author{
Wen Chen \\ International College, Jiangsu Normal University, Xuzhou, China \\ Email: chenw@jsnu.edu.cn
}

How to cite this paper: Chen, W. (2020). International Students' Coping Strategies and Psychological Adaption during Early the COVID-19 Outbreak Period in China. Open Journal of Social Sciences, 8, 29-40. https://doi.org/10.4236/jss.2020.88003

Received: June 20, 2020

Accepted: August 8, 2020

Published: August 11, 2020

Copyright $\odot 2020$ by author(s) and Scientific Research Publishing Inc. This work is licensed under the Creative Commons Attribution International License (CC BY 4.0).

http://creativecommons.org/licenses/by/4.0/

\begin{abstract}
This study aims to understand international students' coping strategies and psychological adaption during the early pandemic of 2019 Coronavirus (COVID-19). By using the convenience and purposive sampling strategy, we selected four participants who were staying in mainland China at the outbreak of COVID-19. They were asked to keep diaries for 3 weeks and attend an interview afterwards. Analysis of participants' diaries and interview transcriptions indicated that international students' source of information about COVID-19 was mainly from English websites; their solutions in the special period were to stay at home; they isolated themselves from the public, wore facial masks when going out, received timely support from their educational institution and did many self-relaxing exercises. Psychologically speaking, they felt panicked at the beginning and gradually became calm; initiatives and measures implemented by governments at all levels in China during the pandemic have won their high praise and China's image has become better, more trustworthy and reliable. These findings provide valuable insights about international students and educational institutions around the world as COVID-19 is continuing; they also add more evidence for positive psychology; that is, individuals' positive feelings largely depend on the environment where they live, such as their teachers, universities, and the society.
\end{abstract}

\section{Keywords}

COVID-2019, International Students, Coping Strategy, Psychological Wellbeing, Chinese Image

\section{Introduction}

At the end of December 2019, an unknown virus outbroke in Wuhan, China, which was later named "COVID-19" by World Health Organization (WHO) on 
February 11, 2020 (China Organ, 2020). This new virus spreads fast and widely, and it infects people easily (Zhang et al., 2020). The COVID-19 outbreak happened at the time of traditional Chinese spring festival, when a population of $300,000,000$ had planned to travel in the holiday (Xinhua, 2020). The population mobility provided a favourable condition for the wide spread of COVID-19 (Cai et al., 2020). As the situation got worse, WHO held an urgent meeting, announcing the COVID-19 a "Public Health Emergency of International Concern (PHEIC)" (China, 2020). According to the International Health Regulations (IHR), a public health emergency of international concern is an unusual event that poses public health risk to other countries through international spread of the disease and may require a coordinated international response (China Organ, 2020). Being a PHEIC, it means that the impact of COVID-19 has exceeded one country; COVID-19 becomes an international concern which needs the corporation from the whole world to defeat it.

Being aware of the seriousness of COVID-19, the Chinese government acted positively and actively at the very beginning of its outbreak, such as shutting down workplaces and public transportation; calling for self-isolation at home and wearing facial masks. State Ministry of Education in China executed the emergency plan for public health emergencies in the education system on January 21th; then educational institutions at each level were closed. It seems that a pause button was pressed and the vast landscape of China lost its original vitality. Internationally, many countries took immediate actions to protect their citizens who were then in China. For example, the US government withdrew all its non-emergent citizens and their relatives from Wuhan on January 23 and prohibited all Chinese citizens to enter the US border from February 3. The Australia government also made an announcement on February $1^{\text {st }}$ that except their citizens and permanent residents, other people who have entered Chinese border during the past 14 days were not allowed to enter Australia (Sohu, 2020). It seemed that just over one night, mainland China had been isolated from the rest of the world.

As a teacher of international students, I was quite worried about my students who only expected to spend a short winter break to travel around China. Some students were at the stage of planning their trips, but more of them had already been in the middle of their journey. They were all stuck by the unprecedented pandemic and need to face the difficulty situation alone in an alien country. I would like to explore how they suffered from this pandemic. In order to further understand their circumstances, three research questions will be addressed, which are:

1) What were the means adopted by international students in coping with the COVID-19 pandemic?

2) What were international students' psychological changes during COVID-19 pandemic?

3) What were international students' comments on the initiatives taken by the Chinese government during COVID-19 outbreak? 


\section{Research Method}

In order to answer these questions listed above, qualitative research methods have been adopted as they can yield rich and insightful results.

\subsection{Participants}

Through convenience and purposive sampling strategy, four participants who were staying in mainland China during early COVID-19 were selected. These participants were conveniently chosen as they were from a university in eastern China, where the author works. They were also purposefully chosen because their living places and conditions differed. At this special period, all people were told to isolate themselves from the public by staying indoors; therefore, living conditions played a decisive role in affecting an individual's experience. Detailed information of four participants is provided in Table 1.

\subsection{Methods}

Data were collected by means of reflective diary and interview. Reflective diary was an important way for students to record what they experienced every day. Participants were asked to keep a diary describing what they did and their feelings from February $5^{\text {th }}$ to $25^{\text {th }}, 2020$. They were told to use either Chinese or English to keep diaries, and eventually, all diaries were kept in English language. On the day of February 26, 2020, we collected 80 diary entries, totaling 20,000 words. More or less, each dairy recorded students' coping strategies in dealing with COVID-19 in these days, their psychological changes and comments. Then, Students were asked to attend an interview session on February $26^{\text {th }}$ to discuss with the author ideas unclear in the diary.

\subsection{Data Analysis}

Data analysis began with coding diary texts into small accessible units by using Kvale's (1996) meaning interpretation approach. Then, a word or word phrase presenting the meaning of that segment was assigned as a label (Cohen, Manion, \& Morrison, 2011). By doing this, 375 pieces of reflective sentences describing nine themes emerged finally. An example of diary excerpt and how a reflective sentence was coded can be seen in Table 2. The entire set of coding themes will be presented and discussed in the next section.

Table 1. Participants' information.

\begin{tabular}{|c|c|c|c|c|c|}
\hline Name & Gender & Nationality & $\begin{array}{c}\text { Length of } \\
\text { living in China }\end{array}$ & $\begin{array}{l}\text { Place of } \\
\text { residence }\end{array}$ & $\begin{array}{l}\text { Stay in China or } \\
\text { return home }\end{array}$ \\
\hline Mati & $\mathrm{M}$ & Pakistan & 3 years & $\begin{array}{l}\text { Double-bedroom } \\
\text { on campus }\end{array}$ & Stay in China \\
\hline Islam & $\mathrm{M}$ & Pakistan & 3 years & $\begin{array}{l}\text { Single-bedroom } \\
\text { on campus }\end{array}$ & $\begin{array}{l}\text { Stay in China then } \\
\text { return to Pakistan }\end{array}$ \\
\hline Anna & $\mathrm{F}$ & Venezuela & 3 years & $\begin{array}{l}\text { Apartment outside } \\
\text { campus }\end{array}$ & Stay in China \\
\hline Juny & $\mathrm{M}$ & Pakistan & 2 years & $\begin{array}{l}\text { Cousin's house } \\
\text { outside campus }\end{array}$ & Stay in China \\
\hline
\end{tabular}


Table 2. Sample diary excerpt and coding.

\begin{tabular}{|c|c|}
\hline An excerpt from diary & Code \\
\hline $\begin{array}{l}\text { I follow the instructions given by the government } \\
\text { and my teacher to stay in the dormitory }\end{array}$ & Self-isolation \\
\hline
\end{tabular}

\section{Results}

Themes in relation to three research questions are presented in Figure 1 and they will be detailed in this section.

\subsection{Coping Strategies}

\subsubsection{Update Information about COVID-19}

Websites, Chinese teachers and friends of their native country are major sources for students to update their COVID-19 information. It is worth noting that due to students' Chinese proficiency level, they relied more on English websites to acquire information, and they communicated with teachers or peers in English or their native language. For instances:

I get to know COVID-19 information mainly from BBC and CNN. The first thing I do every day is to browse news online with the hope that COVID-19 has been controlled. (Mati)

My main source of COVID-19 is "China Daily" and "One belt One Road Education". In addition to these, my teacher and friend often tell me or send me the latest news. (Islam)

In January this year when my friend and I were travelling in Nanjing (a city in China), he suddenly shifted his attention from his cellphone and seriously said that we should wear a mask. He told me that there was a province named " $\mathrm{Hu}$ bei" (at that time, he could barely pronounce "Hubei" correctly), where a contagious virus was spreading. I then read that news and realized how terrible the situation had already been. That day was January 20, 2020. (Juny)

Mati, Islam and Juny relied heavily on English websites to acquire COVID-19 news. For students living on campus, teachers were an important source of information; and for students living outside campus, their immediate friends played an equally important role as external sources.

\subsubsection{Self-Isolation}

Self-isolation is the major measure advocated by the Chinese government, and it was carefully practiced by the international students. For instances:

I follow the instructions given by the government and my teacher to stay in the dormitory. (Islam)

I keep my dormitory tidy and clean as I stayed in it every day. I sterilize my hand when touch things, I cook by myself in the kitchen. (Mati)

I try to stay at home as much as I can. I only went out once during last four weeks. (Anna)

Islam, Mati and Anna commented that they stayed in the dormitory/at home as much as they could, just like Chinese citizens. 


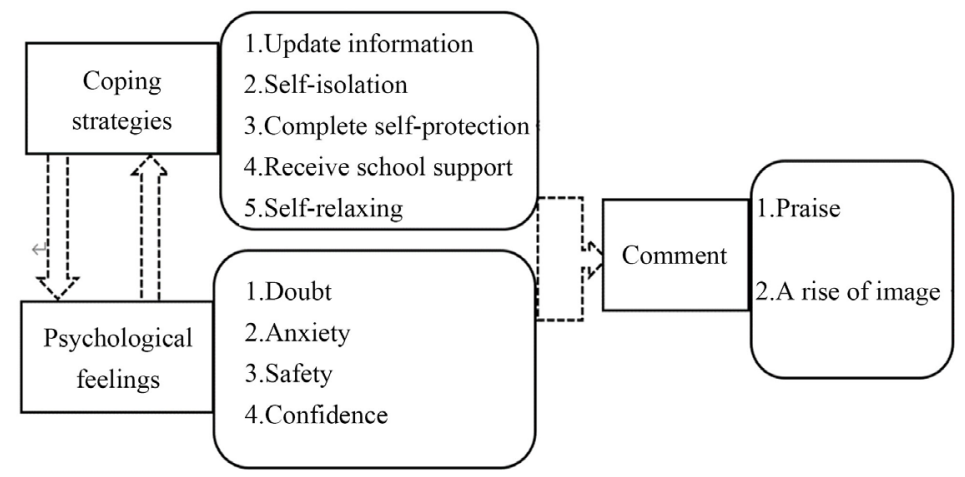

Figure 1. Results of participants' coping strategies, psychological feelings and comments towards COVID-19.

\subsubsection{Complete Self-Protection When Going Out}

How to protect oneself when going to public places was instructed clearly by medical experts through various mass media. Data showed that international students had mastered the right way of doing it. For example:

In case that I have to buy life necessities, I will make full protection, such as wearing two facial masks, glasses and gloves, after return to my dormitory, I will dispose the masks and gloves, wash my hand, change my clothes, and disinfect my shoes with disinfectant. (Islam)

At that time, I wore a mask, a pair of gloves and used disinfectant, once returned home, I sprayed my whole body with alcohol; threw up my clothes into the washing machine and took a shower immediately. My husband went out more often than me and he adopted similar precautious methods as well. When washing vegetables, I use white vinegar and hot water. At present, we only eat fruits with skins (such as banana, orange and apples), and do not eat those that are exposed in the air (such as strawberry and grape). (Anna)

Islam and Anna used facial masks, glasses, gloves and disinfectant to protect themselves when going out; when returned, they disposed them all and washed their clothes. By doing these, the chance of getting affected by the contagious virus was greatly reduced. These measures are just what every Chinese citizen practiced then.

\subsubsection{Support from School}

Students who stayed in their dormitory on campus appreciated the support provided by the university. Here is an example:

Actually, I don't go outside often as my class teacher regularly delivers us food and daily supplies. The university informs us channels to book goods, which will be ready to pick up at the school gate. (Mati)

According to Mati, the university not only instructed them how to book delivered goods, but also helped with delivering daily necessities. These measures greatly facilitated students' daily life in the special period.

\subsubsection{Self-Relaxing}

When doing self-isolation, students tried to find their own solutions to over- 
come daily boredom and dullness. Here are some comments:

Every day, I do some indoor exercise, cooking and reading, and house cleaning every other day. (Anna)

I actively do exercises to increase my body's resistance to virus. Occasionally, I take a walk on campus. (Mati)

Both Anna and Mati chose to do physical exercise to temporarily release the tension exerted by the epidemic and keep themselves healthy.

\subsection{Psychological Feelings}

In addition to measure that students have taken, our data also revealed their emotional fluctuation at the outbreak of COVID-19.

\subsubsection{Doubt}

As COVID-19 is a new virus, no one knows what it is and how destructive it will be to human beings. Therefore, students actively searched for information to know more about it.

It is important to note that in my native country (Venezuela) I never had the experience of a pandemic or large-scale death due to a virus. When I heard the news for the first time here in China a month ago, my immediate reaction was confusion, for me viruses like that were just movie and science fiction stuff, so I was totally uninformed. (Anna)

Anna said that she was confused about the virus at the very beginning as she never experienced such pandemic in the past, and she even refused to believe what had happened. Differently, students who lived on campus did not experience this uncertainty. For instance:

After the outbreak, our university was shut down and no one was allowed to enter without permission. Our class teacher keeps a close eye on us daily by asking our health conditions and providing us with necessary living supplies using online communicative tools. He is the best teacher I ve ever met. Dormitory managing stuff cares us very much as well. My parents in Pakistan asked me to return but I refused. I have two reasons: firstly, I am living a safe, good life here; secondly, if I choose to return to Pakistan, I may risk of the lives of all people in my country by increasing their chances of getting infected. Staying in China also means that I believed that she can defeat this virus, and I know that China overcame SARS in 2003. My decision is fully supported by my family. (Mati)

Personally, I feel safe because the campus security department took some steps and those steps were really self-explanatory and I was totally agreed with them. Secondly, many measures taken by Chinese government assured me that it's going to be fine even I make my family calm by telling them $1 \mathrm{~m}$ completely safe so no worries. I feel happier once knowing that we'll have online classes. Then I made a decision to return to my home country because I can take an incredible intern job while attending online classes. This decision is good for my future development. (Islam)

According to Mati and Islam, the universities took many immediate actions 
including shut down campus and assisted them with life necessities; therefore, they felt safe and comforted his parents is Pakistan not to worry about him.

\subsubsection{Anxiety}

After a short period of confusion about the contagious virus, students living outside campus began to feel anxious about the uncertainty of the future.

When the days went by and I understood that it was reality I felt very scared, then I thought that a country like this as developed, as advanced as it was possible that something like this happened, my first thoughts were of denial, I refused to believe that in the best country something like this will happen in the world. (Anna)

After hearing the news of COVID-19 burst, many ideas came into my mind. I immediately bought a pack of facial masks, and at that time, facial masks were easily accessible. I searched all day online to acquire the information about COVID-19 and precautionary measures. The next day, I made a decision to move to my cousin's house with my friends. We felt anxious again after a short relief after arrival because we were told to isolate ourselves at home unless there was emergency for us to go out to deal with. The first day at my cousin's house was tough because we were not used to the new environment, and my friend got a cold soon. We had to go to the hospital to see the doctor. Fortunately, it was only a common cold and we were told to go back home with some prescribed medicine. As time passed by, rumors about COVID-19 began to spread; we were worried about if provisions were sufficient. (Juny)

Here, Juny felt very anxious when being told to isolate himself in his cousin's house, the comfortless and new environment put more anxiety on him. The worst thing was that his friend was sick and the symptom looked similar to COVID-19. His tension continued because of the rumors of insufficient living supplies. It is worth noting that students living on campus had hardly reported any anxiety.

\subsubsection{Safety}

As time passed by, the Chinese government's determination to support its people to overcome the difficulties was evident to the public; supply was sufficient and stable; everyone could easily acquire the latest news ..., therefore, students felt assured again. Here are some comments:

My concern did not stop until I heard a lot of news that the government will punish any unauthorized price rise at this special period, and personally saw that everything in supermarket kept the original price. Today, I went out of the house and happily found that people in the street were increasing, more business were re-opened. People recollect their confidence in life, therefore, my worries were gradually disappearing. (Juny)

My daily mood depends on the information and news that I receive, some days I feel panicky, but I generally feel calm. I control my thoughts so that they do not alter my mood and I am confident that following the prevention and 
safety measures everything will be fine. For my sake, for my mental health and that of my family, I have avoided receiving information and news from alarmist people. (Anna)

When personally saw the prices in the market and people's life were back to normal, June felt safe as well. Anna's mood depended more on the information she received; however, she generally felt calm. She knew how to keep herself and her family positive.

\subsubsection{Confidence}

Though participants who lived on campus showed a consistent belief that the virus would be defeated, participants lived out of campus gradually built up their confidence in overcoming the difficulty. For example:

Measures that have been adopted are incredible. Discipline is the main characteristic of China. It is incredible to see so much effort, control, collaboration and work in such short period. It is important to highlight the high level of awareness of the Chinese people. All have joined towards achieving the protection objective, all collaborate, all are attentive to new security and prevention measures to implement and comply with them. No country in the world is so prepared and qualified to face this situation because in addition to the efficiency and excellence of the government, Chinese citizens are also people with very high levels of awareness and commitment. (Anna)

Anna praised the Chinese government and Chinese people. It is just the measures initiated by the government and the high level of people's awareness that restored her confidence in defeating the epidemic.

\subsection{Comments to the Chinese Government's and the University's Reactions}

During the sudden COVID-19 outbreak, many initiatives have been implemented by Chinese government. These measures have taken people's life safety as the first priority; however, these have restricted convenience in daily life and freedom to some extent. When facing with the choice between life and freedom, the Chinese government chose the former one without hesitation. We are interested in whether international students agree with such a choice. Here are some related statements by students:

My passion for China is from early childhood. I think it is one the greatest countries of the world. When having the opportunity to study in China, I find that it is greater than my imagination. I feel peaceful and safe when staying here. I believe that COVID-19 is temporary. I care about the health condition of me and my family, so I do try everything that I can to ensure this. I try to think positive things only and learn new skills to make my life meaningful. (Anna)

I $m$ satisfied with the government's actions as I mentioned above. I was not panicky and the steps taken by government and university security department are absolutely right. Asking people to stay home and identifying every single infected person by checking their body temperature isolating infected persons 
from others are right and I think it's only way to stop the spread of virus when we are clear that there is no vaccine yet for this virus. I was in China till the afternoon of 16-Feb-2020, I was not panicky, nor was I worried and was waiting for classes to start. I moved out later because classes were online and situation was not clear and I had a good internship opportunity in my country. For a student it is necessary to manage time without affecting studies so I thought it's time to deal with it and visit my parents moreover. In china I was a responsibility of teachers to some extent so I thought it would be good for me to move out and do my own things. Though $P \mathrm{~m}$ in my country now, if there is any necessity and China needs me I am willing and make myself available. (Islam)

Anna talked about her love for China from her early childhood; when she actually stayed here, this feeling was even stronger. She said that she felt peaceful and safe here, and she was confident that the pandemic was temporary. Islam said what the Chinese government had done was absolutely right. He did not feel anxious at all. The start of on-line classes made him very happy because he could handle study, family and future job plan together.

\section{Discussion}

The first research question dealt with international students' coping strategies of COVID-19. Firstly, they found reliable sources of information to keep themselves updated about the development of VOCID-19. In this age of information, websites are definitely the main means for students to acquire information. It is worth noting that due to a lack of Chinese proficiency or reading habit, students preferred to browse through news reports in English website. Influential English websites such as China Daily, BBC, CNN became students' primary choices when searching for COVID-19 information. This reminds news media outlets that when providing news, all ethnic groups in China should be covered; news should be reported in multiple languages to ensure the latest policies and measures are accurately delivered. Though many foreign websites also report COVID-19 situations in China, a local perspective may be more relevant and useful for those who are living there. Secondly, policies to minimize the risk of being affected by the virus, such as self-isolation, wearing facial masks, etc., were well adopted by international students. Participants believed that these were very effective measures since the vaccine had not been invented yet. Thirdly, the university provided a lot of support for students to overcome the difficult time in this pandemic. This is an important step as it could not only help students overcome life inconvenience but also made them feel cared for. Lastly, it is good to see that students could find their own way to relax. Some did exercise at home, some walked around on campus. Knowing how to get relaxed from pressure is important. Seen from international students' coping strategies for COVID-19, we know that Chinese citizens adopted similar strategies. What is different is that international students do not have immediate family support, so, university is their solely support in mainland China. University is their family, their harbor 
to keep away from storms, and the crucial point is to feel safe. In the early days of the epidemic, facial masks were different to buy, so the university provided them with free facial masks to wear; when it would risk one's health to go shopping, the university staff helped deliver goods to them. Just because of these effective measures, students felt safe and then convinced their oversea parents that they were healthy and safe in China. Measures that have been taken in this pandemic have brought positive influence to international students staying in mainland China. In the end of 20th century, Chairman of the American Psychological Association (Martin E.P. Seligman) proposed a subfield of psychology-positives psychology, which focuses on human's advantages and virtues. Martin E.P. Seligman believes that positive organization system is one of the three cornerstones in positive psychology. Within any social organization, such as a university, affective feelings between individuals, gratefulness and tolerance will enhance an individual's positive experiences (Dang, 2015). Action speaks louder than words. Measures implemented by the university during the COVID-19 outbreak period have had a positive influence on international students and increased their positive emotions when staying China.

The second research question was about international students' psychological well being. When experiencing a change in living, students, especially those with less support (living outside campus) suffered much psychological stress, which could be divided into four obvious stages: "doubt-anxious-safe-confident". COVID-19 is an unprecedented event in human history, no one knows what it actually is and expects that it is so serious at the beginning phase; therefore, many people doubted it. As the virus spread and its contagiousness known to the public, people started to hoard up goods to avoid going out, which led rumors of insufficient supply in the market. International students started to feel anxious about how to keep themselves safe and survive in a foreign country as they did not have any advantage of either buying provisions or keeping themselves in good health conditions compared with local citizens. The overwhelming loneliness and anxiety were commonly seen among them. The fact was that not only among international students, similar worries were lingering among Chinese citizens. For example, it was reported that people hoarded up facial masks, foodstuffs and medicines. At the time when the whole nation was experiencing a feeling of uncertainty, the government chose to timely and openly provide information so that the public could have a clear understanding of how the situation was, what the government had done and how to protect themselves to the maximum extent. These measures made students feel assured. One student commented that a new hospital named "Huoshenshan" was built within 10 days, which was unbelievable for him. Another student mentioned that the self-discipline habit of Chinese people is out of her expectation. With just one command from the central government, the whole nation paused: public transportation was halted, businesses were closed down, residents stayed indoors ... When the nation was fighting with the virus by applying many unusual measures, any potential side effect was controlled to a minimum extent. An example is that the adop- 
tion of on-line teaching policy enabled the continuity of schooling and students' learning progress was not affected (Ministry of Education, 2020). When getting to know more about the virus, seeing the measures that government have taken, students become confident in surviving this difficult period.

The last research questions explored students' comments on the Chinese government in this pandemic. All participants showed a high level of praise and endorsement to Chinese government and people. Participants who lived on campus also commented highly on the school, their teacher, and dormitory security guard. A responsible attitude and strong measures bring a rise of Chinese image in international students.

\section{Conclusion and Implications}

Before concluding, it has to be acknowledged that the number of participants in this study is limited. It only provides a peek on international students' life and psychological changes during the outbreak of COVID-19 pandemic. However, it timely analyzed the coping strategies and psychological changes of international students who live in mainland China. Findings suggest that international students turned to popular English websites for the latest information; they isolated themselves indoors, practiced complete protection when going out, received support from the university and did self-relaxation exercises while staying at home. Psychologically, they experienced a variety of emotions including doubt, anxiety, safety and confidence. These findings are especially inspirable for those who are still suffering from the epidemic. Measures implemented by the Chinese government in this epidemic have won high praise from international students, and their attitudes towards China become more positive and the image of China in their mind is of a more reliable and dependable one.

The current study has provided some practical implications as well. Though international students are a special minority group, their ways of dealing with changes in life and psychological changes are similar to the majority of Chinese citizens. Nevertheless, they are more vulnerable than the majority of local citizens as their family can hardly provide them with any material support. Their educational institution is probably the only source they can rely on; and measures implemented by China are key to ensuring their wellbeing and safety. As the COVID-19 pandemic is still a great public-health threat across the world, hopefully, this study can provide educational institutions with some insights into what international students have experienced, so they know better how to improve their own students' psychological well-being.

\section{Fund}

Funded by State Language Commission (Project No. ZDI135-82).

\section{Conflicts of Interest}

The author declares no conflicts of interest regarding the publication of this paper. 


\section{References}

Cai, H., Zhu, Y., Lei, L., Pan, C., Zhu, L., Li, J., Gu, J., \& Hao, Y. (2020). Novel Coronavirus Pneumonia Epidemic-Related Knowledge, Behaviors and Psychology Status among College Students and Their Family Members and Friends: An Internet-Based Cross-Sectional Survey. Chinese Journal of Public Health, No. 3, 1-4.

China (2020). The Novel Coronavirus Epidemic Is Classified as PHEIC by WHO. https://news.china.com/internationalgd/10000166/20200131/37751082.html

China Organ (2020). Public Health Emergency of International Concern (The Fight against COVID-19). http://kns.cnki.net/kcms/detail/21.1234.r.20200228.1002.002.html

Cohen, L., Manion, L., \& Morrison, K. (2011). Research Methods in Education (7th ed.). London: Routledge.

Dang, X. (2015). A Positive Psychology Perspective on Mental Health Education of Tertiary Students. Chinese Adult Education, 23, 58-60.

Kvale, S. (1996). InterViews: An Introduction to Qualitative Research Interviewing. Thousand Oaks, CA: Sage.

Ministry of Education (2020). Novel Coronavirus Infection Prevention and Control Work Carried Out by the Ministry of Education. http://www.moe.gov.cn/jyb_xwfb/gzdt_gzdt/s5987/202001/t20200122_416316.html

Sohu (2020). Australia's Prime Minister Announced the Ban on the Entry of People from Mainland China, Effective Today. https://www.sohu.com/a/369956252_241241

Xinhua (2020). In 2020, the National Passenger Volume of Spring Festival Transportation Will Reach about 3 Billion Person Times. http://www.xinhuanet.com/2019-12/18/c_1125362460.htm

Zhang, C., Xu, J., Geng, X., Li, C., Yan, J., Wang, Z., Ding, X., Lu, S., Zhang, J., Zhang, X., \& Chen, Y. (2020). The Prevention and Control Strategies of the Outpatient Department for Novel Coronavirus Pneumonia Epidemic. Chinese Health Service Management, No. 3, 1-10. 